\title{
A Novel Vesicular Nanoproniosomal Gel Loaded Losartan Potassium: Formulation, Ex Vivo Evaluation, In Vivo Bioavailability and Antihypertensive Studies
}

\section{Yeni Bir Vesiküler Nanoproniozomal Jel Yüklü Losartan Potasyum: Formülasyon, Ex Vivo Değerlendirme, In Vivo Biyoyararlanım ve Antihipertansif Çalışmalar}

\section{SABAREESH et al. Nanoproniosomal Gel of Losartan Potassium SABAREESH ve ark. Losartan Potasyum Nanoproniozomal Jel}

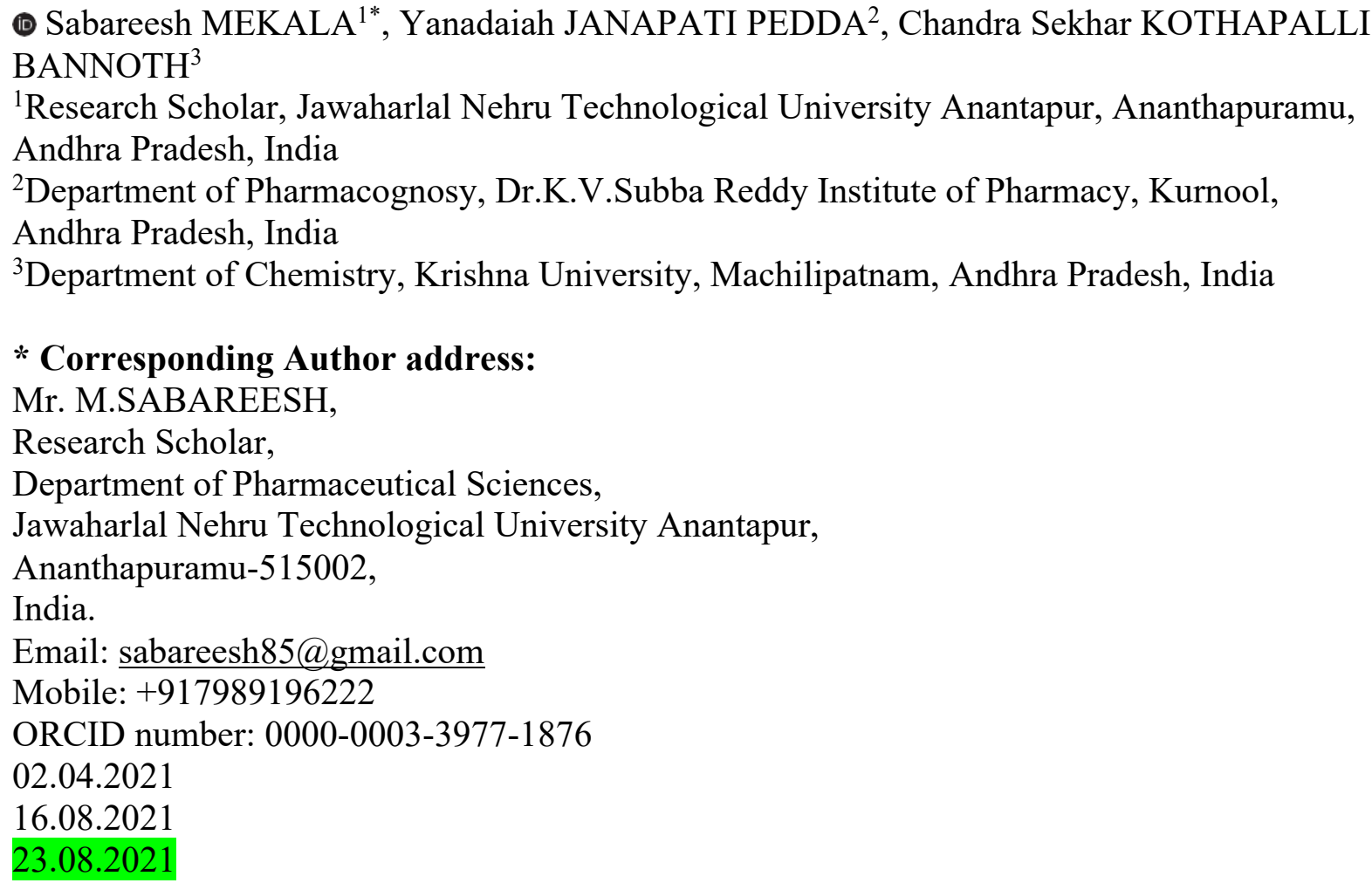

\footnotetext{
ABSTRACT

Objective: The ambition of the investigation was to formulate and evaluate the Losartan Potassium (LP) nanoproniosomal gel to cure the hypertension by transdermal application and to provide better bioavailability.

Materials and Methods: The nanoproniosomal gel was formulated by materials such as nonionic surfactants, cholesterol, lecithin using the Coacervation-phase separation (CPS) method.
} 
The formulated gels were evaluated for $\mathrm{pH}$, viscosity, rate of spontaneity, entrapment efficiency, vesicle size analysis, zeta potential, ex vivo permeation study, skin irritation study, in vivo bioavailability study, in vivo antihypertensive study, and in vitro-in vivo correlation (IVIVC).

Results: Physical characterization was obtained within the acceptable limits. The ex vivo diffusion study depicted the permeation around $47.25 \%$ to $82.49 \%$ across the albino rat skin in $24 \mathrm{~h}$ for all the formulations. Among them, NLPG2 was considered as the better formulation due to the representation of good characteristics than other formulations in a lot of parameters such as physicochemical evaluation, ex vivo skin permeation studies, permeation kinetics, and other studies. The skin irritation test denoted that there was no irritation after the application and it was safest to use on the skin. The in vivo bioavailability studies indicated that AUC represents the good bioavailability of about 167.51 fold in comparison with the marketed tablet. The In vivo antihypertensive investigation depicted that formulation NLPG2 was fruitful to recover the rat BP to normal healthy condition in experimental animals. The IVIVC indicated the in vitro (ex vivo) data could reflect the physiological situations identical to in vivo circumstances.

Conclusion: The nanoproniosomal gel is a capable transdermal system to deliver the LP to cure the hypertension. It is applicable for once-a-day controlled release formulation.

Keywords: Losartan Potassium, Ex vivo Permeation studies, In vivo antihypertensive studies, In vivo bioavailability studies, In vitro-in vivo correlation.

\section{$\ddot{\mathbf{O Z Z}}$}

Amaç: Araştırmanın amacı, hipertansiyonu transdermal uygulama ile iyileştirmek ve daha iyi biyoyararlanım sağlamak için Losartan Potasyum (LP) nanoproniozomal jeli formüle etmek ve değerlendirmekti.

Malzemeler ve Yöntemler: Nanoproniozomal jel, Koaservasyon-faz ayırma (CPS) yöntemi kullanılarak iyonik olmayan yüzey aktif maddeler, kolesterol, lesitin gibi malzemelerle formüle edildi. Formüle edilen jeller $\mathrm{pH}$, viskozite, spontanlık oranı, tuzak etkinliği, vezikül boyutu analizi, zeta potansiyeli, ex vivo geçirgenlik çalışması, cilt tahrişi çalışması, in vivo biyoyararlanım çalışması, in vivo antihipertansif çalışma ve in vitro-in vivo korelasyon için değerlendirildi. (IVIVC).

Sonuçlar: Fiziksel karakterizasyon kabul edilebilir sınırlar içinde elde edildi. Ex vivo difüzyon çalışması, tüm formülasyonlar için albino sıçan derisinde 24 saat içinde yaklaşı $1 \mathrm{k} \%$ 47.25 ila\% 82.49 nüfuz etmeyi gösterdi. Bunlar arasında, NLPG2, fizikokimyasal değerlendirme, ex vivo cilt geçirgenlik çalışmaları, geçirgenlik kinetiği ve diğer çalışmalar gibi birçok parametrede diğer formülasyonlara göre iyi özelliklerin temsilinden dolayı daha iyi formülasyon olarak kabul edildi. Cilt tahriş testi, uygulama sonrası tahriş olmadığını ve ciltte kullanımın en güvenli olduğunu gösterdi. İn vivo biyoyararlanım çalışmaları, AUC'nin pazarlanan tablete kıyasla yaklaşık 167.51 katlık iyi biyoyararlanımı temsil ettiğini gösterdi. In vivo antihipertansif araştırma, NLPG2 formülasyonunun deney hayvanlarında sıçan BP'sini normal sağlıklı duruma getirmek için verimli olduğunu gösterdi. IVIVC, in vitro (ex vivo) verilerin in vivo koşullarla özdeş fizyolojik durumları yansıtabileceğini gösterdi.

Sonuç: Nanoproniozomal jel, hipertansiyonu iyileştirmek için LP'yi ileten yetenekli bir transdermal sistemdir. Günde bir kez kontrollü salım formülasyonu için geçerlidir.

Anahtar Kelimeler: Losartan Potasyum, Ex vivo Geçirgenlik çalışmaları, In vivo antihipertansif çalışmalar, In vivo biyoyararlanım çalışmaları, In vitro-in vivo korelasyon.

\section{INTRODUCTION}

Nowadays, the transdermal drug administration is the most successful and fruitful drug delivery and became an inventive target for research in systemic drug delivery. It releases the drug across the skin into the blood circulation at a controlled, constant and predetermined rate. This delivery has various advantages such as non-invasive administration, bypasses the 
GI tract, prevents the gastric pain and overcomes the gastrointestinal degradation, selfadministration, reduces the number of doses, increases the patient compliance with tolerance, enhances the bioavailability, maintains steady-state plasma drug concentration, improves the safety and therapeutic efficiency of drugs, decreases the side effects and provides easy termination of a drug in problematic cases.

A single drug delivery system cannot fulfill all the characteristics required for the safest drug administration, but some research works have been developed through novel vesicular approaches like niosomes, ethosomes, liposomes, etc. to achieve controlled or targeted drug delivery. All these vesicles have some chemical and physical complications such as hydrolysis or oxidation, sedimentation, aggregation, fusion. Hence, the provesicular concept (proniosomes) has emerged to solve the stability problems of the conventional vesicular

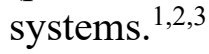

Proniosomes are nano-sized vesicular structures of dry, free-flowing powder (or) gel with drug encapsulation in the vesicle that produce multilamellar niosomal dispersion after hydration. The proniosome powder form is hydrated to ensure quick formation of dispersion of niosomes before administration by little stirring with a hot aqueous liquid and is favorable for administration with oral or other routes. In the case of proniosomal gel, proniosomes are converted into niosomes in situ by absorbing the water from skin after topical application and contacts the stratum corneum, and increase the fluidity and permeability of the skin. This mechanism was depicted in Figure 1. The proniosomes contribute the constant and controlled release of drugs, improvement of penetration, reduced lethal effects; and also avoid the physical complications of niosomal vesicles. ${ }^{4,5,6}$

Priniosomal gel preparations are semisolid products formed by the CPS method which involves the admixture of nonionic surfactant, cholesterol in a minimal amount of alcohol with consecutive hydration with aqueous fluid. They have glassy appearance as a translucent gel structure that improves the physical stability. The non-ionic surfactant and cholesterol ratio can alter both the release characteristics and the encapsulation efficiency of the entrapped drugs. ${ }^{7,8,9}$

The gels became more familiar because of ease of applicability and good percutaneous permeation characteristics than other semi-solid preparations. Gels can combat the physiological stress, and adopt the shape of the applied area and can control the drug release. Hence, proniosomes are commonly prepared in a gel formulation. ${ }^{10,11}$

After application of proniosomes on the skin, they undergo hydration and form niosomes which stick to the skin surface. These niosomes undergo a process of endocytosis and lysis of membrane by lysozymes, which release the encapsulated drug into the blood. If a drug penetrates the stratum corneum, then it easily passes through the epidermis and dermis layers and can be absorbed into systemic circulation via capillaries. ${ }^{6}$ This mechanism of permeation was shown in Figure 2.

LP is an angiotensin II receptor antagonist, employed to treat the high blood pressure to reduce the strokes and also used to retard long-term kidney damage. It has ideal features like small molecular weight which is 423 (below 600 daltons), low drug dose (25-50 mg), very less half-life $(2 \mathrm{~h}$ ), and poor bioavailability (oral) for suitability of transdermal formulation. Hence, it was selected in the nanoproniosomal transdermal formulation to provide the drug delivery at a slower and constant rate via skin to ensure an effective therapeutic drug level for a prolonged time and also to improve the bioavailability. ${ }^{12}$

(https://www.drugbank.ca/drugs/DB00678, https://www.drugs.com/losartan.html)

The prime goal of the investigation was to formulate the LP nanoproniosomal gel to treat the hypertension and to deliver the entrapped medicament efficiently for prolonged period through the transdermal route to improve the permeability and bioavailability of drug.

\section{MATERIALS AND METHODS}




\section{Materials}

LP was acquired from Vijayasri Chemicals, Hyderabad, India as a gift sample. Cholesterol, Soya Lecithin, Span 20, Span 40, Tween 60, Tween 80 were obtained from Himedia Laboratories Pvt. Ltd, Mumbai, India. Methylprednisolone acetate (MPA) injection (Depo$\mathrm{Medrol}^{\mathrm{TM}}$ ) manufactured by Pfizer was purchased from a medical shop.

\section{Methods}

\section{Preparation of Nanoproniosomal Gel}

It was produced by the CPS method. In this technique, the nonionic surfactants were weighed and transferred to a glass container (wide mouthed) with tight closure and an accurate amount of drug, cholesterol, and lecithin were added to the glass vial. After mixing all these ingredients in a glass vial, ethanol was included and mixed up thoroughly. Heat the above solution until the cholesterol, lecithin, and drug were completely dissolved in surfactant (around 20-25 min) until the appearance of a clear gel. Then phosphate buffer (aqueous phase) was added and heated lightly till a clear solution produced (nearly $10 \mathrm{~min}$ ). Thereafter, it was cooled while mixing it with a glass rod at regular intervals that resulted in the development of nanoproniosomal gel. ${ }^{13,14,15}$ The method was represented pictorially in Figure 3. The composition was illustrated in Table 1.

\section{Evaluation of Nanoproniosomal Gel}

\section{pH}

The $\mathrm{pH}$ was determined in triplicate by using a digital $\mathrm{pH}$ meter. ${ }^{15,16}$

\section{Viscosity}

The viscosity was determined in triplicate by Brookfield Viscometer (DV-E). ${ }^{15,16}$

\section{Vesicle size determination (Microscopic evaluation)}

The proniosomal gel $(50-100 \mathrm{mg})$ was mixed with phosphate saline $(10 \mathrm{ml})$ in a test tube by manual shaking and the resulting niosomes were observed at $100 \mathrm{X}$ using optical microscope to determine the size of vesicles. ${ }^{8,14,17}$

\section{Rate of spontaneity}

Spontaneity is expressed as the number of niosomal vesicles obtained spontaneously from the proniosomal gel on hydration for 15-20 min. The specific quantity $(20 \mathrm{mg})$ of proniosomal gel was dispersed in saline water in a suitable glass jar and warmed a little for the development of niosomes and a drop was mounted on the Neubauer's chamber to enumerate the vesicles number (niosomes). ${ }^{8,13,18}$

\section{Entrapment efficiency}

The proniosomal gel $(100 \mathrm{mg})$ was dissipated in purified water and warmed gently for the development of niosomes. This suspension was centrifuged at $5^{\circ} \mathrm{C}$ for $40 \mathrm{~min}$ at $18000 \mathrm{rpm}$ (Remi CPR-24 axis). The supernatant liquid was analyzed by spectrophotometric method at $234 \mathrm{~nm}$ for the drug content. $8,15,18$

The entrapment efficiency was determined by $\%$ Encapsulation Efficiency= [1-(Unencapsulated drug/Total drug) $]$ x 100

\section{Zeta potential}

It is the amplitude of net charge on the surface of niosomes. The high value of zeta potential denotes the repulsive forces between the vesicles that prevents the aggregation or fusion of vesicles and forms uniformly distributed stable product. It was determined by using HORIBA SZ- 100 Zeta meter. ${ }^{13,19,20}$

\section{Ethical clearance approval}

Ethical clearance was approved from the IAEC for the experimentation on animals for the research work entitled, "A Novel Vesicular Nanoproniosomal Gel Loaded Losartan Potassium: Formulation, Ex Vivo Evaluation, In Vivo Bioavailability and Antihypertensive Studies". The protocol of this experimentation was sanctioned from IAEC, Protocol Number: 
SVCP/IAEC/I-015/2019-20 dt 29.05.20. The study was executed as per the recommendations of CPCSEA.

\section{Experimental animals}

Albino wistar male healthy rats were (weighing around $250 \pm 25 \mathrm{~g}$ ) opted for skin irritation studies, in vivo bioavailability studies, and in vivo antihypertensive studies. All the animals were healthy during the study of experiment. The rats were preserved at standard conditions of laboratory, with relative humidity of $55 \pm 5 \%$, temperature of $25 \pm 1^{\circ} \mathrm{C}$, and $100 \%$ fresh air exchange. They were placed properly in polypropylene cages, with free approach to a standard diet (Lipton feed) and water ad libitum. The dose was calculated as per the weight of body and surface area ratio of animals.

\section{Ex Vivo Skin permeation studies}

These studies were performed by using a modified Franz-diffusion cell. It has a receptor chamber about $60 \mathrm{ml}$ volume and a surface area of $3.14 \mathrm{~cm}^{2}$. In this study, Albino rat weighing 150-200 $\mathrm{g}$ was selected and sacrificed by ether, and nearly 4 to $5 \mathrm{~cm}^{2}$ (thickness) of the skin was collected from the shaved region of the abdomen, and was positioned between the receptor and donor compartments. A specific amount of the gel was lodged on the skin approaching the donor chamber and the phosphate buffer was loaded in the receptor chamber. The temperature was maintained at $37 \pm 0.5^{\circ} \mathrm{C}$ through a hot plate (thermostatic) fitted to a stirrer (magnetic). The diffusion solution was agitated by a magnetic bead (teflon-coated) placed in the receptor compartment. The samples were collected at suitable time intervals, and were analyzed by spectroscopic method at $234 \mathrm{~nm} .{ }^{8,13,14,19,21}$

\section{Skin irritation studies}

It was carried out on healthy normal albino rats as per the recommendations of OECD. In this test, precise amount of proniosomal gel $(0.5 \mathrm{~g})$ was uniformly applied to 3 rats on the previously shaven area of skin surface roughly $2.54 \times 2.54 \mathrm{~cm}^{2}$, and were returned to cages. After $24 \mathrm{~h}$, the proniosomal gel was removed by washing with water. This study was done on one rat initially (Initial skin irritation test) and later conducted on two rats (confirmatory skin irritation test). The erythema and edema were to be observed, and graded as per the visual scoring scale. ${ }^{14,15,21,22,23}$ (https://www.oecd.org/env/test-no-404-acute-dermal-irritationcorrosion-9789264242678-en.htm)

The erythema scale is as follows:

$0 . \quad$ none

1. slight

2. $\quad$ well defined

3. moderate

4. $\quad$ scar formation

The edema scale is as follows:

$\begin{array}{ll}0 . & \text { none } \\ 1 . & \text { slight } \\ 2 . & \text { well defined } \\ 3 . & \text { moderate } \\ 4 . & \text { severe }\end{array}$

\section{Stability studies}

The stability is the potential of a particular product in a favorable container to remain with the characteristics including chemical, physical, therapeutic, microbiological, and toxicological throughout the shelf-life. It was conducted as per the ICH guidelines and it was done to detect the drug degradation from proniosomal gel during the storage period. In this test, the formulated gels were preserved in aluminum foil closed glass jars at refrigeration temperature $\left(5^{\circ} \mathrm{C} \pm 3^{\circ} \mathrm{C}\right)$, room temperature $\left(25^{\circ} \mathrm{C} \pm 2^{\circ} \mathrm{C}, 75 \% \mathrm{RH} \pm 5 \% \mathrm{RH}\right)$, oven $\left(45^{\circ} \mathrm{C} \pm 2^{\circ} \mathrm{C}\right)$ 
for 45 days. The samples were observed, checked and collected at particular time intervals, and analyzed for various evaluation parameters. ${ }^{8,14,24}$

\section{In vivo bioavailability studies}

Albino wistar male healthy rats were employed in this study. In this study, 12 Albino rats were taken and were categorized into 2 groups- Group A and B each containing 6 rats. The preferred proniosomal gel (transdermal drug treatment) was given to Group A. The microporous adhesive tape was used to preserve the gel at the application site. Before the topical application, the dorsal area of the hair was cautiously shaved and washed with distilled water, followed by an alcohol swab and patted dry. The marketed tablet (antihypertensive drug) was given orally to Group B. Then rats were kept in the animal chamber and supplied with food and water. Then the blood samples $(0.5 \mathrm{ml})$ were collected at the tail vein of rats at $0.5,1,2,4,8,12,18$, and $24 \mathrm{~h}$ in micro tubes consisting the anticoagulant (sodium citrate buffer). The blood samples were then centrifuged for $5 \mathrm{~m}$ at $4500 \mathrm{rpm}$ to get plasma samples and were deproteinized by acetonitrile, centrifuged and the supernatant liquid was separated and finally analyzed by using HPLC analysis.

\section{HPLC analysis}

The quantification of the drug was done by using a HPLC spectrophotometer (Agilent). It comprised of a UV detector and a C18 column (reversed-phase $5 \mu \mathrm{m}, 4.6 \mathrm{~mm} / 250 \mathrm{~mm}$ ). The mobile phase (solvent) was composed of acetonitrile and phosphate buffer $\mathrm{pH} 7.2$ (65\%:35\% ratio) and was filtered through a membrane filter $(0.45 \mu \mathrm{m})$ and also subjected to an ultrasonicator. The rate of flow was controlled at $0.8 \mathrm{ml} / \mathrm{m}$ for chromatographic separation and analysis. The temperature of the column was fixed at $25^{\circ} \mathrm{C}$ and samples were inserted into the column at a fixed volume of $20 \mu 1$.

\section{Sample preparation}

Protein precipitation technique can be used for the analysis, where plasma $(0.5 \mathrm{ml})$ was added to precipitating agent $(0.5 \mathrm{ml})$ like perchloric acid or acetonitrile, or methanol, then subjected to vortex $(5 \mathrm{~m})$ and centrifuged for $3 \mathrm{~m}$ at $10000 \mathrm{rpm}$. The supernatant was collected and dried by stream of nitrogen. The residue was then vortexed and added to mobile phase (100 $\mu \mathrm{l})$ for $20-30 \mathrm{~s}$ and centrifuged for $2 \mathrm{~m}$ at $10000 \mathrm{rpm}$. Finally, $20 \mu \mathrm{l}$ of sample was introduced into a HPLC device. From the results obtained, various pharmacokinetic parameters such as $\mathrm{C}_{\max }$ (maximum plasma drug concentration), $\mathrm{T}_{\max }$ (time to reach maximum plasma concentration), $\mathrm{K}_{\mathrm{E}}$ (elimination rate constant), $\mathrm{K}_{\mathrm{a}}$ (absorption rate constant), $\mathrm{AUC}_{0-\mathrm{t}}, \mathrm{AUMC}_{0-}$ t, Mean residence time (MRT), Elimination half-life $\left(\mathrm{t}_{1 / 2}\right)$ and the Relative bioavailability (F\%) were calculated. Cmax and Tmax were directly obtained from the plasma profiles (plasma concentration-time data). $\mathrm{K}_{\mathrm{a}}$ and $\mathrm{K}_{\mathrm{E}}$ were ascertained by employing the residual method. AUC, AUMC were computed from the trapezoidal method. MRT was calculated by formula, MRT=AUMC/AUC; Elimination half-life $\left(\mathrm{t}_{1 / 2}\right)$ was computed by, $\mathrm{t}_{1 / 2}=\ln$ $2 / \mathrm{K}_{\mathrm{E}}{ }^{13,14,16,17,25}$

Statistical scrutiny was done with software (Graph-Pad Instat 3) using ANOVA (one-way analysis of variance) and the difference with $p<0.05$ was designated significant.

\section{In vivo antihypertensive studies}

Albino wistar male healthy rats were selected for this study. 30 rats were taken and separated into five categories (Group A to E) each carrying 6 rats. Group A was considered as control and in other groups (Group B to E) hypertension was caused by subcutaneous administration of MPA injection $(20 \mathrm{mg} / \mathrm{kg} / \mathrm{w})$ for 2 weeks. These treatments were indicated in Table 2. Before the topical application, the dorsal area of the hair was cautiously shaved and washed with distilled water, followed by an alcohol swab and patted dry. Then, the formulation NLPG2 was uniformly applied over the skin surface. The microporous adhesive tape was used to preserve the gel at the application site. Then rats were sent back to the animal chamber and given free approach to food and water. The blood pressure was ascertained at 
specified time intervals from the tail of rat for $24 \mathrm{~h}$ using a rat BP device (Biopac). It has a tail-cuff, a scanner, an animal chamber affixed to the body of primary instrument containing a digital display for BP. ${ }^{14,18,21}$

\section{Statistical analysis:}

The data was statistically scrutinized by one-way analysis of variance. A paired t-test and Dunette test were used to test the different formulations using software (Graph-Pad Instat 3) with level of significance $(p<0.05)$.

\section{IVIVC}

It was performed to ascertain the therapeutic effectiveness of the formulation and to correlate the in vitro data (ex vivo data) with in vivo data. The IVIVC plot of LP Proniosomal gel was constructed by plotting the graph by taking in vitro $\%$ permeation on the $\mathrm{x}$-axis with in vivo $\%$ absorption of the formulation on the y-axis. ${ }^{14}$

\section{RESULTS AND DISCUSSION}

The nanoproniosomal gels were formulated and evaluated for physicochemical studies, ex vivo permeation studies, skin irritation test, in vivo bioavailability studies, in vivo antihypertensive studies, and IVIVC study.

\section{Physicochemical characterization of proniosomal gel}

The LP nanoproniosomal gel was characterized for physicochemical properties and the results were given in Table 3. The $\mathrm{pH}$ of all the formulations was around 6.8 and 7.1 which means that they are safer to administer through the transdermal route. The vesicle size of the formulations shows that when compared to the size of proniosomes formed from spans (Span 20, Span 80); the tweens showed a much more increase in size which reduces the entrapment efficiency of the drug. Hence, the proniosomes formed from the spans having a smaller vesicle size and greater encapsulation efficiency. The rate of spontaneity was ranged from 718 which indicates the number of niosomes formed from the proniosomes after hydration. The Entrapment Efficiency was ranged as $42.54 \%$ - $80.86 \%$. The viscosity was obtained as 8529-10410 cps. All the prepared formulations depicted better physicochemical attributes and are not beyond the margins.

\section{Microscopic evaluation}

The microscopic evaluations of the formulation shown that the formulations were in good physical shape and size. The microscopic images were shown in Figures 4-5.

\section{Ex Vivo Skin Permeation Studies}

The skin permeation data was shown in Table 4 and Figure 8. The percentage drug permeation of NLPG2 was found to be the highest among all, around $82.49 \%$ than other formulations. The smaller vesicular size due to nanoproniosomal technology may be the reason for the increase in drug diffusion rate and extent.

\section{Permeation data analysis}

The permeability parameters like permeation coefficient, flux, enhancement ratio were significantly increased in nanoproniosomal formulations. Among them, NLPG2 showed good permeation data than other formulations. The kinetic permeation data was presented in Table 5.

Among all formulations, NLPG2 was shown good physicochemical characteristics, better skin permeation, and permeation kinetics. Hence, it was considered as the best formulation for next studies.

\section{Vesicle size and Zeta potential analysis}

The proniosomal size plays a vital role in drug release; hence it is an important parameter to be determined. The particle size and the PI value of the best formulation were obtained as $48.7 \mathrm{~nm}$ and 1.698 (which indicates a very broad distribution). The zeta potential represents the stability of vesicles. The Zeta potential of the best formulation was obtained as $-80.8 \mathrm{mV}$ and reported as excellent stability. These graphs were illustrated in Figures 6 to 7. 


\section{Skin Irritation Studies}

These were performed according to OECD guidelines and the results shown no changes like Edema and Erythema. Hence, the formulation passed the test and is safe to be used on Human skin. The skin irritation data and images were denoted in Tables 6, 7, and Figure 9.

\section{Stability Studies}

Physical appearance and homogeneity were good during the storage period. The Stability studies performed showed that the formulation NLPG2 is highly stable at different temperatures for the prescribed time. Hence, the formulation passed the stability studies. The stability data were depicted in Table 8 .

\section{In vivo bioavailability studies}

These were performed to ascertain the bioavailability and efficiency of the formulation with the marketed oral product. The LP plasma concentrations in rats treated with proniosomal gel formulation NLPG2 were significantly higher than those treated orally with a pure drug suspension. The pharmacokinetic parameters of wistar rats after application of LP proniosomal gel were shown in Table 9 and Figure 10. The $\mathrm{C}_{\max }$ value of the proniosomal gel formulation was $36.08 \pm 3.78 \mathrm{ng} / \mathrm{ml}$, which was lower as compared to $\mathrm{C}_{\max }$ of the marketed drug, i.e., $44.49 \pm 1.96 \mathrm{ng} / \mathrm{ml}$. The $\mathrm{T}_{\max }$ values of the proniosomal gel formulation and marketed drug were $4.82 \pm 0.55 \mathrm{~h}$ and $2.15 \pm 0.34 \mathrm{~h}$ respectively. AUC is a primary parameter in determining the drug bioavailability from the product, and also it indicates the total integrated region below the plasma concentration-time profile and denotes the whole quantity of drug absorbed into the blood after the administration. $\mathrm{AUC}_{0-\mathrm{t}}$ for the proniosomal gel formulation was higher $(473.44 \pm 15.84 \mathrm{ng} . \mathrm{h} / \mathrm{ml})$ than $\mathrm{AUC}_{0-\mathrm{t}}$ of the marketed drug $(282.63 \pm 11.37 \mathrm{ng} . \mathrm{h} / \mathrm{ml})$. Statistically, $\mathrm{AUC}_{0-\mathrm{t}}$ of the proniosomal gel formulation was significantly higher $(p<0.05)$ than the marketed drug. A higher amount of drug in blood indicated better systemic and prolonged absorption of LP from the proniosomal gel with the marketed drug.

\section{In vivo antihypertensive studies}

In this study, the normal healthy rats were successfully induced with hypertension by injecting MPA for two weeks and maintained in hypertension condition for further $72 \mathrm{~h}$. The Proniosomal gel formulation NLPG2 was found to decrease the BP significantly $(p<0.001)$ in proximity of healthy normal condition and it was maintained for $24 \mathrm{~h}$ (Table.10). This indicates that the drug was permeated and constantly released into the systemic circulation for $24 \mathrm{~h}$ in rats. The post-treatment BP values in the treatment group (D) were compared with the control group (A). The percentage rat BP reduction of NLPG2 and Placebo NLPG2 was $25.26 \%$ and $0.10 \%$, respectively (Table.10). NLPG2 was success to revert the rat BP to normal healthy condition. The above mentioned outcomes revealed that the nanoproniosomal formulations have a bright destiny to manage the hypertension that needs to be approved by clinical research.

\section{IVIVC}

It was constructed by taking in vitro $\%$ permeation on the $\mathrm{x}$-axis with in vivo $\%$ absorption on the $\mathrm{y}$-axis with regression value $\left(\mathrm{R}^{2}\right) 0.9992$. This correlation indicated that the in vitro (ex vivo) permeation studies could reflect the physiological situations identical to in vivo conditions. The IVIVC plot was illustrated in Figure 11.

\section{CONCLUSION}

The nanoproniosomal LP gel was formulated to improve the bio-availability and permeation of the drug. Various formulations of nanoproniosomal gel were prepared by the CPS method. Among them, NLPG2 showed better characteristics than other formulations in several aspects. Hence, the formulation NLPG2 was selected as the best formulation and is suitable for controlled release once a day formulation to treat the hypertension. From the results, it 
could be concluded that the LP loaded nanoproniosomal gel proves to be beneficial and acts as an alternative to the conventional dosage form to manage the hypertension.

\section{ACKNOWLEDGMENT}

We are grateful to the Chairman and Principal of Sree Vidyanikethan College of Pharmacy, Tirupati, Andhra Pradesh, India for providing all the necessary and lab resources to perform the research.

\section{ABBREVIATIONS}

LP: Losartan potassium; BP: Blood pressure; MPA: Methylprednisolone acetate; CPS: Coacervation-Phase separation; IAEC: Institutional Animal Ethical Committee; CPCSEA: Committee for the purpose of control and supervision of experiment on animals; HPLC: High-Performance Liquid Chromatography; IVIVC: In vitro-In vivo Correlation; UV: Ultra Violet; OECD: Organisation for Economic Co-operation and Development; AUC: Area Under the Curve; AUMC: Area Under the First Moment Curve; ICH: International Council for Harmonisation; PI: Polydispersity Index.

\section{REFERENCES}

1. Radha GV, Sudha Rani T, Sarwani B. A review on proniosomal drug delivery system for targeted drug action. J Basic Clin Pharm. 2013;4:42-48.

2. Jangam Payal R, Thombre Nilima A, Gaikwad Pallavi N. A Review: Proniosomes as a Novel Drug Delivery System. Asian J Pharm Tech. 2017;7:166-174.

3. Srikanth, Anand Kumar Y, Mallikarjuna Setty C. Formulation and Evaluation of Maltodextrin Based Doxorubicin HCl Proniosomes. Res J Pharm Technol. 2019;12:27762780 .

4. Indira U and Uma Shankar M.S. Proniosomes as a drug carrier: A review. Int J Pharm Sci Res. 2012;3:4617-4625.

5. Venkata Ramesh Yasam, Satya Lavanya Jakki, Jawahar Natarajan and Gowthamarajan Kuppusamy. A review on novel vesicular drug delivery: proniosomes. Drug Deliv. 2013;1-7.

6. Swati Mittal, Amit Chaudhar, Anjali Chaudhary and Ankit Kumar. Proniosomes: the effective and efficient drug-carrier system. Ther Deliv. 2020;2019-0065.

7. Kondawar MS, Kamble KG, Malusare MK, Waghmare JJ and Shah ND. Proniosome Based Drug Delivery System for Clotrimazole. Res J Pharm Technol. 2011;4:1284-1287.

8. Ankur gupta, Sunil kumar prajapati, Bala murugan M, Mamta singh, Daksh Bhatia. Design and development of a proniosomal transdermal drug delivery system for captopril. Trop J Pharm Res. 2007;6:687-693.

9. Waghmode maya and Shruthi ashar. Proniosomal drug delivery systems: An overview. Int J Pharm Chem Sci. 2012;1:1044-1056.

10. Maryam khatoon, Kiyafat ullah shah, Fakhar ud din, Shefaat ullah shah, Asim ur rehman, Naz dilawar et al. Proniosomes derived niosomes:Recent advancements in drug delivery and targeting. Drug delivery. 2017;24:56-69.

11. Gopala Krishna Murthy TE, Sai Kishore V. Formulation and Evaluation of Transdermal Gels of Diltiazem Hydrochloride. Indian J Pharm Educ Res. 2008;42:272-276. 12. Umekar M.J., Biyani D.M., Amgaonkar Y.M., Bhoyar P.K., Lade U.B., Kalsait R.P. Formulation Development and Evaluation of Transdermal Drug Delivery System of Antihypertensive Drug. Research J Pharm and Tech. 2010;3(3):753-757.

13. Ming Ming Wen, Ragwa M.Farid, and Abeer A.Kassem. Nano-proniosomes enhancing the transdermal delivery of mefenamic acid. J Liposome Res. 2014;24:280-289. 14. Viney lather, Dharmpal Sharma and Deepti pandita. Proniosomal gel- mediated transdermal delivery of bromocriptine: in vitro and ex vivo evaluation. J Exp Nanosci. 2016;11:1044-1057. 
15. Sabareesh M, Yanadaiah JP, Chandra Sekhar KB. A Novel Vesicular Approach for Transdermal Administration of Enalapril Maleate Loaded Nanoproniosomal Gel:

Formulation, Ex Vivo Evaluation and In Vivo Antihypertensive Study. International Journal of Applied Pharmaceutics. 2020;12(5):190-202.

16. Nadeem farooqui, Mousumi kar, Ravindra pal singh. Formulation and development of proniosomal gel for transdermal delivery of ketorolac tromethamine. Asian J Pharm. 2016;10:S394-S400.

17. Rishu kakkar, Rao rekha, Dahiya navin kumar, Nanda sanju. Formulation and characterisation of valsartan proniosomes. Maejo Int J Sci Technol. 2011;5:146-158.

18. Ashish Kute, Prakash Goudanavar, Doddayya Hiremath, Reddy SR. Development and Characterization of Perindopril Erbumine Loaded Proniosomal Gel. Asian J Pharm Tech. 2012;2:54-58.

19. Venkata ramesh yasam, Satya lavanya jakki, Jawahar natarajan, Senthil venkatachalam, Gowthamarajan kuppusamy, Sumeet sood et al. A novel vesicular transdermal delivery of nifedipine- preparation, characterization and in vitro/in vivo evaluation. Drug Deliv. 2016;23:619-630.

20. Sandeep Gupta, Dheeraj Ahirwar, Neeraj K Sharma, and Deenanath Jhade. Proniosomal Gel as a Carrier for Improved Transdermal Delivery of Griseofulvin:

Preparation and In-Vitro Characterization. Research J Pharma Dosage Forms and Tech. 2009;1:33-37.

21. Amol Shete, Priyanka Thorat, Rajendra Doijad, Sachin Sajane. Formulation and In Vitro, In Vivo Evaluation of Proniosomal Gel of Neomycin Sulphate. Int J App Pharm. 2019;11:156-163.

22. Sharda Sambharkar, Sarvesh Paliwal, Swapnil Sharma, Bishambar Singh.

Formulation of risperidone loaded proniosomes for effective transdermal delivery: An in vitro and in vivo study. Bull Fac Pharm. (Cairo Univ). 2017;55:239-247.

23. Singh S, Trivedi S, Jain S. Design and development of proniosome based transdermal delivery of ondansetron hydrochloride. Int J Appl Pharm Biol Res. 2012;3:191-201.

24. Ali Nasr, Mona Qushawy, Shady Swidan. Spray Dried Lactose Based Proniosomes as Stable Provesicular Drug Delivery Carriers:Screening, Formulation, and Physicochemical Characterization. Int J App Pharm. 2018;10:125-137.

25. Prem Kumar Y, Vinod Kumar K, Sai Kishore V. Preparation and Evaluation of Diclofenac Niosomes by Various Techniques. Res J Pharm Technol. 2013;6:1097-1101.

26. Abdul Ahad, Mohd. Aqil, Asgar Ali. Investigation of antihypertensive activity of carbopol valsartan transdermal gel containing 1,8-cineole. Int J Biol Macromol. 2014;64:144149.

\section{TABLES}

Table 1. Formulation table of Nanoproniosomal gel of Losartan potassium

\begin{tabular}{|c|c|c|c|c|c|c|c|c|c|c|}
\hline \multirow{2}{*}{$\begin{array}{l}\text { Ingredients } \\
\text { (in mg) }\end{array}$} & \multicolumn{10}{|c|}{ Formulation code } \\
\hline & $\begin{array}{l}\text { NLPG } \\
1\end{array}$ & $\begin{array}{l}\text { NLPG } \\
2\end{array}$ & $\begin{array}{l}\text { NLPG } \\
3\end{array}$ & $\begin{array}{l}\text { NLPG } \\
4\end{array}$ & $\begin{array}{l}\text { NLPG } \\
5\end{array}$ & $\begin{array}{l}\text { NLP } \\
\text { G6 }\end{array}$ & $\begin{array}{l}\text { NLPG } \\
7\end{array}$ & $\begin{array}{l}\text { NLPG } \\
8\end{array}$ & $\begin{array}{l}\text { NLPG } \\
9\end{array}$ & $\begin{array}{l}\text { NLPG } \\
10\end{array}$ \\
\hline $\begin{array}{l}\text { Losartan } \\
\text { Potassium }\end{array}$ & 25 & 25 & 25 & 25 & 25 & 25 & 25 & 25 & 25 & 25 \\
\hline Lecithin & 100 & 100 & 100 & 100 & 100 & 100 & 100 & 100 & 100 & 100 \\
\hline Cholesterol & 100 & 100 & 100 & 100 & 100 & 100 & 100 & 100 & 100 & 100 \\
\hline Span 20 & 1000 & -- & -- & -- & 500 & 500 & 500 & -- & -- & -- \\
\hline Span 80 & -- & 1000 & -- & -- & 500 & -- & -- & 500 & 500 & -- \\
\hline
\end{tabular}




\begin{tabular}{|c|c|c|c|c|c|c|c|c|c|c|}
\hline Tween 20 & -- & -- & 1000 & -- & -- & 500 & -- & 500 & -- & 500 \\
\hline Tween 80 & -- & -- & -- & 1000 & -- & -- & 500 & -- & 500 & 500 \\
\hline Alcohol (ml) & 0.5 & 0.5 & 0.5 & 0.5 & 0.5 & 0.5 & 0.5 & 0.5 & 0.5 & 0.5 \\
\hline $\begin{array}{l}0.1 \% \text { glycerol } \\
\text { solution }(\mathrm{ml})\end{array}$ & QS & QS & QS & QS & QS & QS & QS & QS & QS & QS \\
\hline
\end{tabular}

Table 2. Treatment was given to the different groups of animals

\begin{tabular}{|c|c|c|c|c|}
\hline S.No. & Group & Treatments & $\begin{array}{l}\text { No. of } \\
\text { rats in } \\
\text { group }\end{array}$ & $\begin{array}{l}\text { Measurement of BP at } \\
\text { different time intervals (h) }\end{array}$ \\
\hline 1 & $\mathrm{~A}$ & Control & 6 & $0,1,2,3,4,6,8,10,12,24$ \\
\hline 2 & $\mathrm{~B}$ & Only MPA & 6 & $0,1,2,3,4,6,8,10,12,24$ \\
\hline 3 & $\mathrm{C}$ & $\begin{array}{l}\text { MPA + placebo } \\
\text { NLPG2 }\end{array}$ & 6 & $0,1,2,3,4,6,8,10,12,24$ \\
\hline 4 & $\mathrm{D}$ & MPA + NLPG2 & 6 & $0,1,2,3,4,6,8,10,12,24$ \\
\hline 5 & $\mathrm{E}$ & $\begin{array}{l}\text { MPA + Marketed } \\
\text { tablet }\end{array}$ & 6 & $0,1,2,3,4,6,8,10,12,24$ \\
\hline
\end{tabular}

Table 3. Physicochemical characterization 


\begin{tabular}{llllll}
\hline $\begin{array}{l}\text { Formulation } \\
\text { code }\end{array}$ & pH* & $\begin{array}{l}\text { Vesicle size* } \\
(\boldsymbol{\mu m})\end{array}$ & $\begin{array}{l}\text { Rate of } \\
\text { spontaneity* }\end{array}$ & $\begin{array}{l}\text { Entrapment } \\
\text { efficiency } \% *\end{array}$ & Viscosity (cps)* \\
\hline NLPG-1 & $6.80 \pm 0.12$ & $10.52 \pm 2.37$ & $16.33 \pm 0.21$ & $62.62 \pm 0.24$ & $9840.35 \pm 1.63$ \\
NLPG-2 & $6.91 \pm 0.03$ & $4.81 \pm 0.52$ & $14.22 \pm 2.53$ & $80.86 \pm 0.78$ & $10410.56 \pm 0.81$ \\
NLPG-3 & $6.70 \pm 0.02$ & $21.10 \pm 1.55$ & $10.45 \pm 0.22$ & $55.23 \pm 0.56$ & $10224.93 \pm 1.24$ \\
NLPG-4 & $6.81 \pm 0.15$ & $19.43 \pm 3.18$ & $11.56 \pm 2.25$ & $60.25 \pm 0.78$ & $9190.45 \pm 1.24$ \\
NLPG-5 & $6.82 \pm 0.20$ & $11.62 \pm 2.04$ & $7.78 \pm 3.26$ & $48.64 \pm 0.65$ & $9380.67 \pm 3.26$ \\
NLPG-6 & $7.02 \pm 0.01$ & $19.75 \pm 2.75$ & $8.94 \pm 0.31$ & $42.54 \pm 0.98$ & $10340.20 \pm 1.47$ \\
NLPG-7 & $7.10 \pm 0.23$ & $17.51 \pm 1.56$ & $10.55 \pm 5.52$ & $56.69 \pm 0.65$ & $8529.34 \pm 2.05$ \\
NLPG-8 & $6.82 \pm 0.07$ & $19.80 \pm 2.52$ & $11.82 \pm 3.60$ & $51.45 \pm 0.65$ & $10091.51 \pm 0.81$ \\
NLPG-9 & $6.81 \pm 0.14$ & $16.44 \pm 4.50$ & $7.37 \pm 4.21$ & $42.98 \pm 0.36$ & $10511.28 \pm 0.81$ \\
NLPG-10 & $6.90 \pm 0.25$ & $21.92 \pm 3.75$ & $18.77 \pm 1.55$ & $56.24 \pm 0.65$ & $10220.37 \pm 1.63$ \\
\hline
\end{tabular}

*Average of three values

\pm Standard deviation

Table 4. Ex Vivo Skin Permeation Studies*

\begin{tabular}{|c|c|c|c|c|c|c|c|c|c|c|}
\hline $\begin{array}{l}\text { Time } \\
\text { (h) }\end{array}$ & $\begin{array}{l}\text { NLPG- } \\
1 \%\end{array}$ & $\begin{array}{l}\text { NLPG- } \\
2 \%\end{array}$ & $\begin{array}{l}\text { NLPG- } \\
3 \% \\
\end{array}$ & $\begin{array}{l}\text { NLPG- } \\
4 \%\end{array}$ & $\begin{array}{l}\text { NLPG- } \\
5 \%\end{array}$ & $\begin{array}{l}\text { NLPG- } \\
6 \%\end{array}$ & $\begin{array}{l}\text { NLPG- } \\
7 \%\end{array}$ & $\begin{array}{l}\text { NLPG- } \\
8 \%\end{array}$ & $\begin{array}{l}\text { NLPG- } \\
9 \%\end{array}$ & $\begin{array}{l}\text { NLPG- } \\
10 \%\end{array}$ \\
\hline 0 & 0 & 0 & 0 & 0 & 0 & 0 & 0 & 0 & 0 & 0 \\
\hline 1 & $\begin{array}{l}11.43 \pm \\
0.20\end{array}$ & $\begin{array}{l}13.15 \pm \\
0.12\end{array}$ & $\begin{array}{l}6.28 \pm \\
0.60\end{array}$ & $\begin{array}{l}8.73 \pm \\
0.38\end{array}$ & $\begin{array}{l}12.26 \pm \\
0.20\end{array}$ & $\begin{array}{l}8.49 \pm \\
0.33\end{array}$ & $\begin{array}{l}9.82 \pm \\
0.55\end{array}$ & $\begin{array}{l}14.37 \pm \\
0.04\end{array}$ & $\begin{array}{l}7.33 \pm \\
0.11\end{array}$ & $\begin{array}{l}13.53 \pm \\
0.30\end{array}$ \\
\hline 2 & $\begin{array}{l}19.60 \pm \\
0.31\end{array}$ & $\begin{array}{l}21.26 \pm \\
0.25\end{array}$ & $\begin{array}{l}11.51 \pm \\
0.27\end{array}$ & $\begin{array}{l}12.44 \pm \\
0.49\end{array}$ & $\begin{array}{l}19.68 \pm \\
0.17\end{array}$ & $\begin{array}{l}12.20 \pm \\
0.74\end{array}$ & $\begin{array}{l}13.05 \pm \\
0.06\end{array}$ & $\begin{array}{l}21.60 \pm \\
0.31\end{array}$ & $\begin{array}{l}11.11 \pm \\
0.24\end{array}$ & $\begin{array}{l}21.30 \pm \\
0.62\end{array}$ \\
\hline 4 & $\begin{array}{l}25.83 \pm \\
0.41\end{array}$ & $\begin{array}{l}29.33 \pm \\
0.41\end{array}$ & $\begin{array}{l}16.73 \pm \\
0.49\end{array}$ & $\begin{array}{l}17.86 \pm \\
0.63\end{array}$ & $\begin{array}{l}23.43 \pm \\
0.58\end{array}$ & $\begin{array}{l}16.66 \pm \\
0.07\end{array}$ & $\begin{array}{l}18.10 \pm \\
0.17\end{array}$ & $\begin{array}{l}29.43 \pm \\
0.27\end{array}$ & $\begin{array}{l}16.03 \pm \\
0.75\end{array}$ & $\begin{array}{l}28.59 \pm \\
0.43\end{array}$ \\
\hline $\begin{array}{l}6 \\
8\end{array}$ & $\begin{array}{l}31.57 \pm \\
0.21 \\
37.60 \pm \\
\end{array}$ & $\begin{array}{l}35.67 \pm \\
0.56 \\
43.45 \pm\end{array}$ & $\begin{array}{l}21.80 \pm \\
0.57 \\
26.65 \pm\end{array}$ & $\begin{array}{l}20.02 \pm \\
0.33 \\
25.74 \pm\end{array}$ & $\begin{array}{l}29.68 \pm \\
0.27 \\
34.72 \pm\end{array}$ & $\begin{array}{l}21.04 \pm \\
0.80 \\
26.12 \pm \\
\end{array}$ & $\begin{array}{l}21.19 \pm \\
0.24 \\
25.26 \pm\end{array}$ & $\begin{array}{l}36.58 \pm \\
0.60 \\
42.19 \pm\end{array}$ & $\begin{array}{l}20.77 \pm \\
0.50 \\
24.95 \pm\end{array}$ & $\begin{array}{l}37.22 \pm \\
0.08 \\
46.36 \pm\end{array}$ \\
\hline
\end{tabular}




\begin{tabular}{lllllllllll}
\hline & 0.52 & 0.28 & 0.43 & 0.05 & 0.79 & 0.56 & 0.35 & 0.10 & 0.46 & 0.10 \\
10 & $42.23 \pm$ & $50.66 \pm$ & $31.33 \pm$ & $30.93 \pm$ & $38.57 \pm$ & $30.09 \pm$ & $28.37 \pm$ & $48.65 \pm$ & $27.53 \pm$ & $51.77 \pm$ \\
& 0.12 & 0.31 & 0.50 & 0.80 & 0.24 & 0.44 & 0.61 & 0.07 & 0.71 & 0.20 \\
12 & $49.77 \pm$ & $57.93 \pm$ & $34.61 \pm$ & $34.89 \pm$ & $42.24 \pm$ & $34.27 \pm$ & $32.42 \pm$ & $53.95 \pm$ & $31.81 \pm$ & $56.43 \pm$ \\
& 0.22 & 0.01 & 0.67 & 0.73 & 0.19 & 0.36 & 0.45 & 0.29 & 0.06 & 0.49 \\
14 & $52.40 \pm$ & $62.56 \pm$ & $36.99 \pm$ & $37.22 \pm$ & $44.37 \pm$ & $38.35 \pm$ & $35.57 \pm$ & $57.73 \pm$ & $35.58 \pm$ & $61.60 \pm$ \\
& 0.63 & 0.85 & 0.75 & 0.55 & 0.02 & 0.31 & 0.22 & 0.40 & 0.33 & 0.67 \\
16 & $56.43 \pm$ & $68.23 \pm$ & $38.08 \pm$ & $40.19 \pm$ & $46.67 \pm$ & $43.29 \pm$ & $38.61 \pm$ & $62.14 \pm$ & $38.70 \pm$ & $65.29 \pm$ \\
& 0.23 & 0.14 & 0.61 & 0.19 & 0.13 & 0.02 & 0.05 & 0.59 & 0.63 & 0.50 \\
18 & $62.87 \pm$ & $74.72 \pm$ & $40.63 \pm$ & $42.11 \pm$ & $48.24 \pm$ & $45.25 \pm$ & $41.79 \pm$ & $68.41 \pm$ & $41.91 \pm$ & $70.46 \pm$ \\
& 0.33 & 0.74 & 0.10 & 0.21 & 0.19 & 0.14 & 0.44 & 0.47 & 0.16 & 0.32 \\
20 & $65.50 \pm$ & $78.25 \pm$ & $42.55 \pm$ & $44.46 \pm$ & $50.34 \pm$ & $47.84 \pm$ & $46.51 \pm$ & $70.27 \pm$ & $44.80 \pm$ & $73.34 \pm$ \\
& 0.44 & 0.61 & 0.24 & 0.37 & 0.36 & 0.86 & 0.16 & 0.03 & 0.24 & 0.27 \\
22 & $68.24 \pm$ & $80.12 \pm$ & $45.96 \pm$ & $47.72 \pm$ & $52.36 \pm$ & $49.69 \pm$ & $50.46 \pm$ & $72.52 \pm$ & $48.54 \pm$ & $76.42 \pm$ \\
& 0.64 & 0.18 & 0.09 & 0.53 & 0.24 & 0.77 & 0.25 & 0.30 & 0.80 & 0.18 \\
24 & $71.14 \pm$ & $82.49 \pm$ & $47.25 \pm$ & $49.41 \pm$ & $55.63 \pm$ & $52.13 \pm$ & $53.72 \pm$ & $74.92 \pm$ & $50.45 \pm$ & $78.42 \pm$ \\
& 0.64 & 0.18 & 0.51 & 0.62 & 0.47 & 0.18 & 0.32 & 0.30 & 0.64 & 0.18 \\
\hline
\end{tabular}

*Average of three values

\pm Standard deviation

Table 5: Ex Vivo Permeation kinetics

\begin{tabular}{lllll}
\hline S. No & $\begin{array}{l}\text { Formulation } \\
\text { Code }\end{array}$ & $\begin{array}{l}\text { Permeation } \\
\text { coefficient }(\mathbf{P}) \\
\left(\boldsymbol{\mu g} / \mathbf{c m}^{2} / \mathbf{h}\right) *\end{array}$ & $\begin{array}{l}\text { Flux }(\mathbf{J}) \\
\left(\boldsymbol{\mu g} / \mathbf{c m}^{2} / \mathbf{h}\right) *\end{array}$ & $\begin{array}{l}\text { Enhancement } \\
\text { ratio }\left(\mathbf{E}_{\mathbf{r}}\right)\end{array}$ \\
\hline 1 & Control & $2.25 \pm 0.02$ & $10.12 \pm 0.12$ & - \\
2 & NLPG-1 & $4.86 \pm 0.11$ & $22.47 \pm 0.17$ & 2.16 \\
3 & NLPG-2 & $7.33 \pm 0.08$ & $28.67 \pm 0.04$ & 2.87 \\
4 & NLPG-3 & $3.58 \pm 0.14$ & $13.31 \pm 0.33$ & 1.59 \\
5 & NLPG-4 & $3.67 \pm 0.05$ & $14.88 \pm 0.25$ & 1.63 \\
6 & NLPG-5 & $4.08 \pm 0.13$ & $18.25 \pm 0.57$ & 1.78 \\
7 & NLPG-6 & $3.86 \pm 0.21$ & $16.10 \pm 0.48$ & 1.71 \\
8 & NLPG-7 & $3.92 \pm 0.07$ & $16.32 \pm 0.21$ & 1.74 \\
9 & NLPG-8 & $5.75 \pm 0.04$ & $24.18 \pm 0.33$ & 2.55 \\
10 & NLPG-9 & $3.74 \pm 0.18$ & $15.74 \pm 0.42$ & 1.46 \\
11 & NLPG-10 & $6.15 \pm 0.15$ & $26.80 \pm 0.26$ & 2.73 \\
\hline
\end{tabular}

*Average of three values

\pm Standard deviation 
Table 6. Initial skin irritation test

\begin{tabular}{|c|c|c|c|c|c|c|c|}
\hline No. of & Erythema & & & Ede & & & \\
\hline Rat & $24 \mathrm{~h}$ & $48 \mathrm{~h}$ & $72 \mathrm{~h}$ & $\mathbf{O h}$ & $24 \mathrm{~h}$ & $48 \mathrm{~h}$ & $72 \mathrm{~h}$ \\
\hline 01 & - & - & - & - & - & - & - \\
\hline
\end{tabular}

- Sign indicates no changes or signs observed

Table 7. Confirmatory skin irritation test

\begin{tabular}{lllllllll}
\hline No. of & \multicolumn{3}{l}{ Erythema } & \multicolumn{7}{l}{ Edema } \\
Rat & 0 h & 24 h & 48 h & 72 h & 0 h & 24 h & 48 h & 72 h \\
02 & - & - & - & - & - & - & - & - \\
03 & - & - & - & - & - & - & - & - \\
\hline
\end{tabular}

- Sign indicates no changes or signs observed

Table 8. Stability data

\begin{tabular}{|c|c|c|c|c|}
\hline \multirow[b]{2}{*}{$\begin{array}{l}\text { Storage } \\
\text { period }\end{array}$} & \multicolumn{3}{|c|}{$4^{\circ} \mathrm{C}^{*}$} & \multirow[b]{2}{*}{ pH } \\
\hline & Vesicle Size & $\begin{array}{l}\text { Entrapment } \\
\text { efficiency }\end{array}$ & Viscosity & \\
\hline 15 days & $4.82 \pm 0.12$ & $80.22 \pm 0.35$ & $10525.89 \pm 0.81$ & $6.91 \pm 0.10$ \\
\hline 30 days & $4.84 \pm 0.10$ & $79.71 \pm 0.36$ & $10552.75 \pm 0.80$ & $6.94 \pm 0.03$ \\
\hline 45days & $4.61 \pm 0.14$ & $78.65 \pm 0.65$ & $10586.36 \pm 0.84$ & $6.90 \pm 0.05$ \\
\hline \multirow{2}{*}{$\begin{array}{l}\text { Storage } \\
\text { period }\end{array}$} & \multicolumn{3}{|c|}{$25^{\circ} C^{*}$} & \\
\hline & Vesicle Size & $\begin{array}{l}\text { Entrapment } \\
\text { efficiency }\end{array}$ & Viscosity & pH \\
\hline 15 days & $4.80 \pm 0.02$ & $80.51 \pm 0.25$ & $10502.45 \pm 0.80$ & $6.92 \pm 0.02$ \\
\hline 30 days & $4.86 \pm 0.11$ & $80.11 \pm 0.23$ & $10536.93 \pm 0.71$ & $6.95 \pm 0.08$ \\
\hline 45days & $4.72 \pm 0.15$ & $79.60 \pm 0.56$ & $10558.28 \pm 0.87$ & $6.93 \pm 0.04$ \\
\hline \multirow[b]{2}{*}{$\begin{array}{l}\text { Storage } \\
\text { period }\end{array}$} & \multicolumn{3}{|c|}{$40^{\circ} C^{*}$} & \\
\hline & Vesicle Size & $\begin{array}{l}\text { Entrapment } \\
\text { efficiency }\end{array}$ & Viscosity & pH \\
\hline
\end{tabular}




\begin{tabular}{lllll}
\hline 15 days & $4.82 \pm 0.05$ & $80.62 \pm 0.38$ & $10414.65 \pm 0.68$ & $6.93 \pm 0.11$ \\
30 days & $4.70 \pm 0.13$ & $80.51 \pm 0.49$ & $10425.35 \pm 0.81$ & $6.98 \pm 0.13$ \\
45days & $4.68 \pm 0.14$ & $80.22 \pm 0.47$ & $10465.77 \pm 0.81$ & $6.94 \pm 0.07$ \\
\hline
\end{tabular}

*Average of three values

\pm Standard deviation

Table 9. Pharmacokinetic Parameters after administration of Losartan potassium Proniosomal gel and marketed tablet

\begin{tabular}{lll}
\hline $\begin{array}{l}\text { Pharmacokinetic } \\
\text { Parameters }\end{array}$ & $\begin{array}{l}\text { Losartan potassium } \\
\text { suspension (Oral) }\end{array}$ & $\begin{array}{l}\text { Losartan potassium } \\
\text { Proniosomal gel } \\
\text { (Transdermal) }\end{array}$ \\
\hline $\mathrm{C}_{\max }(\mathrm{ng} / \mathrm{ml})$ & $44.49 \pm 1.96$ & $36.08 \pm 3.78$ \\
$\mathrm{~T}_{\max }(\mathrm{h})$ & $2.15 \pm 0.34$ & $4.82 \pm 0.55$ \\
$\mathrm{t}_{1 / 2}(\mathrm{~h})$ & $1.90 \pm 0.49$ & $5.68 \pm 0.71$ \\
$\mathrm{~K}_{\mathrm{E}}(\mathrm{ng} / \mathrm{h})$ & $0.36 \pm 0.25$ & $0.12 \pm 0.18$ \\
$\mathrm{~K}_{\mathrm{a}}(\mathrm{ng} / \mathrm{h})$ & $1.69 \pm 0.42$ & $0.51 \pm 0.22$ \\
$\mathrm{AUC}_{0-\mathrm{t}}(\mathrm{ng} . \mathrm{h} / \mathrm{ml})$ & $282.63 \pm 11.37$ & $473.44 \pm 15.84$ \\
$\mathrm{AUC}_{0-\infty}(\mathrm{ng} \cdot \mathrm{h} / \mathrm{ml})$ & $0.06 \pm 0.03$ & $59.42 \pm 5.10$ \\
$\mathrm{AUMC}_{0-\mathrm{t}}(\mathrm{ng} \cdot \mathrm{h} / \mathrm{ml})$ & $1448.77 \pm 18.52$ & $4636.48 \pm 26.91$ \\
$\mathrm{AUMC}_{0-\infty}(\mathrm{ng} \cdot \mathrm{h} / \mathrm{ml})$ & $0.99 \pm 0.23$ & $1426.22 \pm 10.67$ \\
MRT $(\mathrm{h})$ & $5.13 \pm 1.13$ & $9.79 \pm 2.06$ \\
Relative bioavailability & -- & $167.51 \pm 7.59$ \\
\hline
\end{tabular}

*Average of three values

\pm Standard deviation 
Table 10. Influence of proniosomal gel formulation of Losartan potassium on mean BP in MPA induced hypertensive rats

\begin{tabular}{|c|c|c|c|c|c|c|}
\hline \multirow[b]{2}{*}{ S.No. } & \multirow[b]{2}{*}{ Group } & \multirow[b]{2}{*}{ Treatments } & \multicolumn{3}{|c|}{ Mean BP (mm Hg)* } & \multirow[b]{2}{*}{$\begin{array}{l}\% \text { Reduction } \\
\text { in } \mathrm{BP}^{*}\end{array}$} \\
\hline & & & $\begin{array}{l}\text { Pre- } \\
\text { treatment }\end{array}$ & $\begin{array}{l}\text { Post- MPA } \\
\text { treatment }\end{array}$ & $\begin{array}{l}\text { Post } \\
\text { Proniosomal } \\
\text { gel treatment }\end{array}$ & \\
\hline 1 & $\mathrm{~A}$ & Control & $\begin{array}{l}122.15 \pm \\
12.12\end{array}$ & -- & -- & -- \\
\hline 2 & $\mathrm{~B}$ & Only MPA & $\begin{array}{l}121.06 \pm \\
5.24\end{array}$ & $\begin{array}{l}160.56 \pm \\
10.28\end{array}$ & -- & -- \\
\hline 3 & $\mathrm{C}$ & $\begin{array}{l}\text { MPA + placebo } \\
\text { NLPG2 }\end{array}$ & $\begin{array}{l}123.20 \pm \\
15.73\end{array}$ & $\begin{array}{l}163.28 \pm \\
16.45\end{array}$ & $163.11 \pm 10.31$ & $0.10 \pm 0.01$ \\
\hline 4 & $\mathrm{D}$ & MPA + NLPG2 & $\begin{array}{l}122.58 \pm \\
10.48\end{array}$ & $\begin{array}{l}162.85 \pm \\
11.42\end{array}$ & $121.70 \pm 9.73$ & $25.26 \pm 1.75$ \\
\hline 5 & E & $\begin{array}{l}\text { MPA+ Marketed } \\
\text { tablet }\end{array}$ & $\begin{array}{l}121.69 \pm \\
7.94\end{array}$ & $\begin{array}{l}161.64 \pm \\
11.43\end{array}$ & $144.84 \pm 7.67$ & $10.39 \pm 1.62$ \\
\hline
\end{tabular}

*Average of six values

\pm Standard deviation

\section{FIGURES}




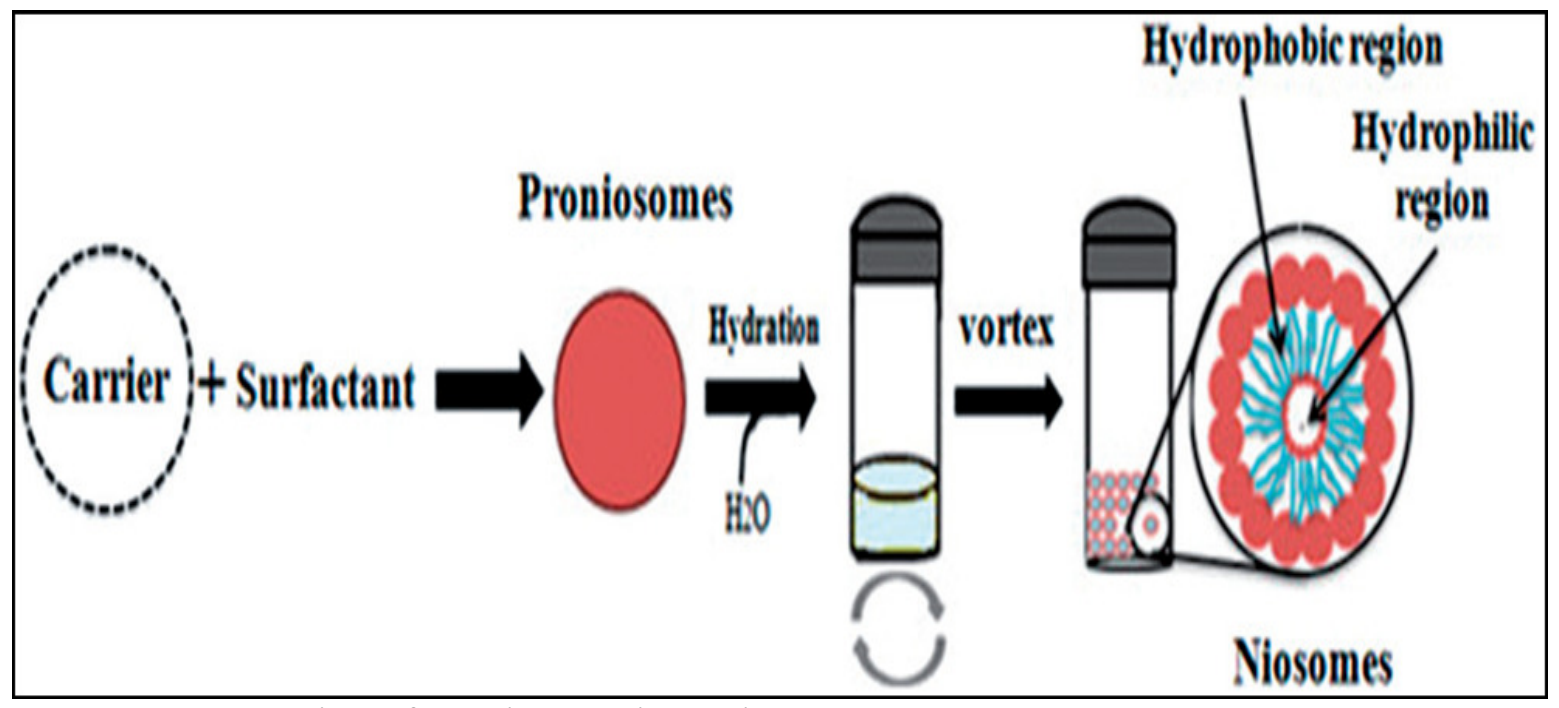

Figure 1. Conversion of Proniosome into Niosome

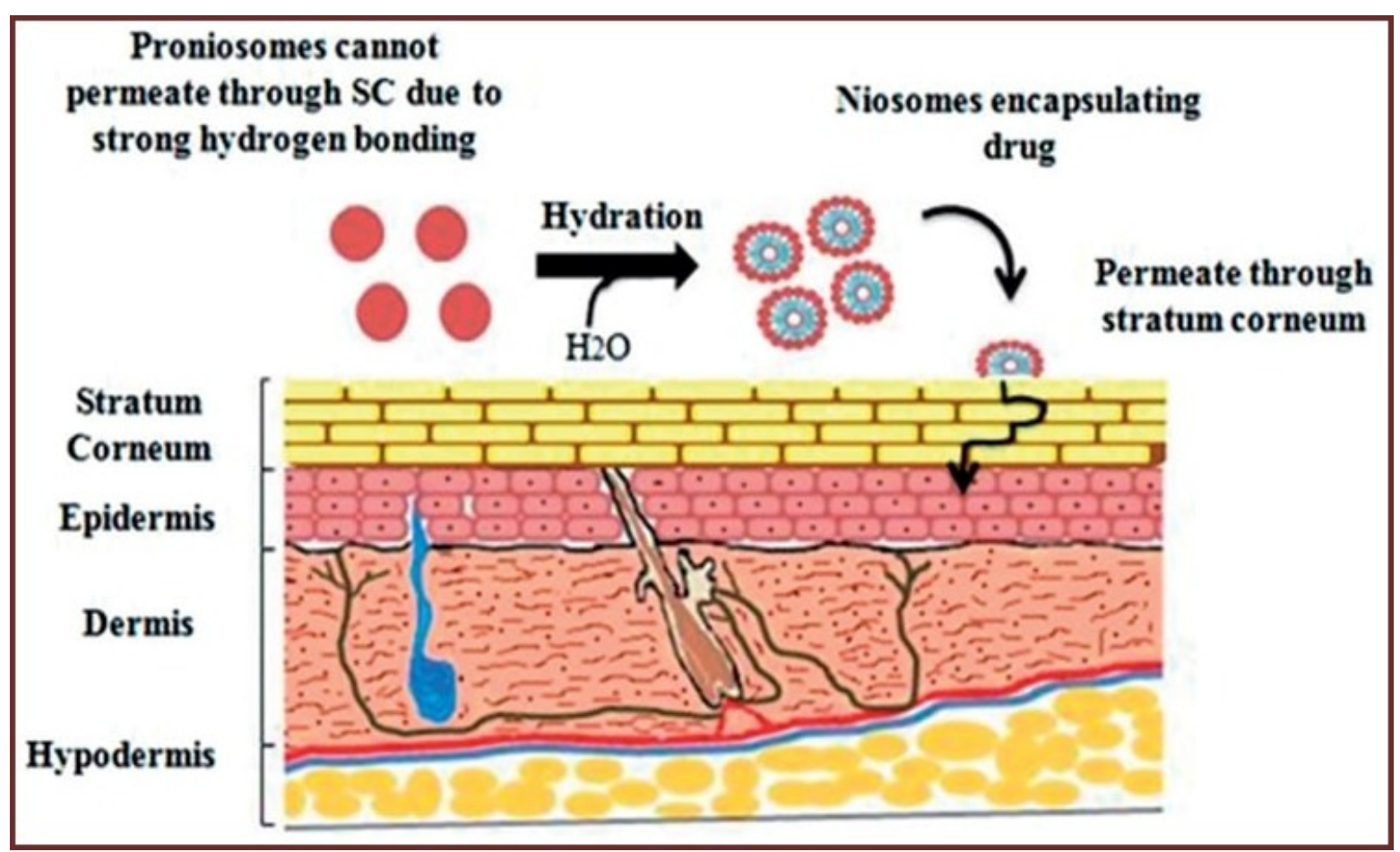

Figure 2. Mechanism of permeation 


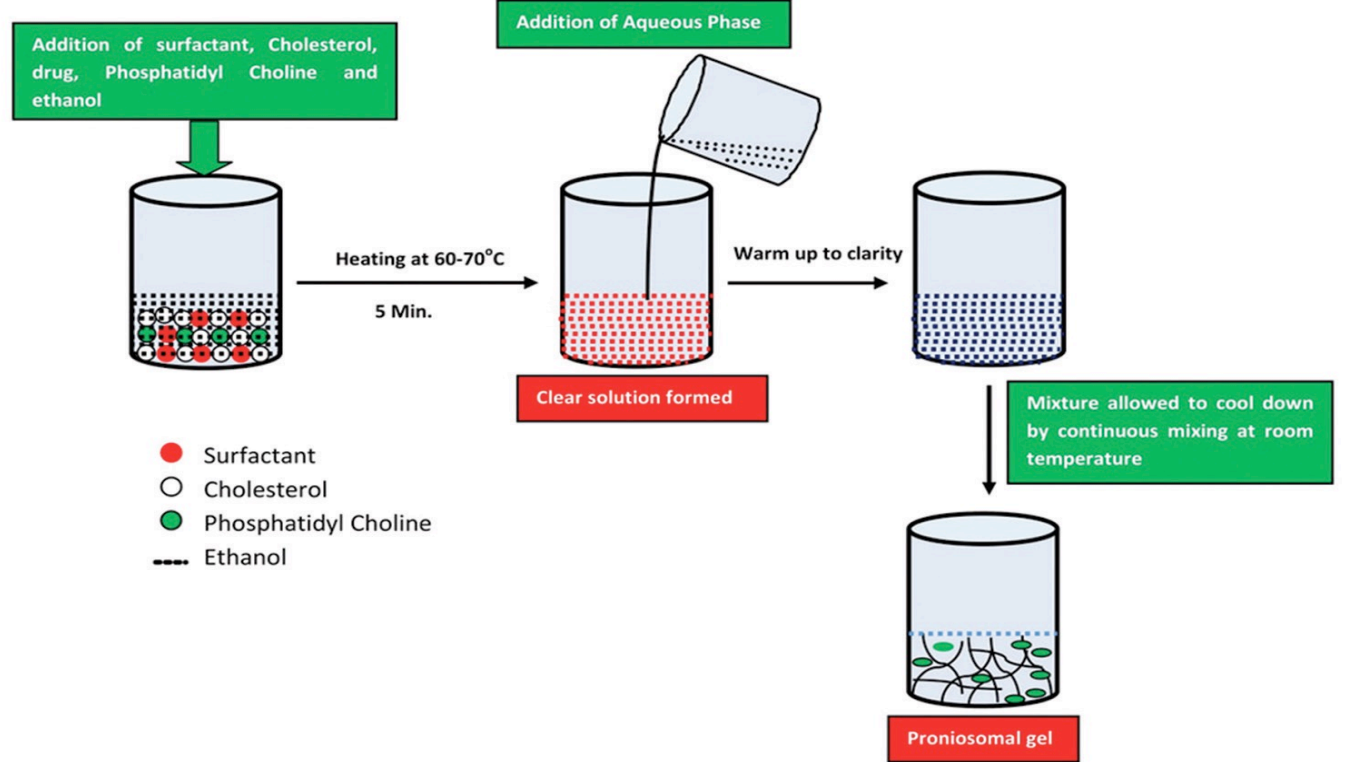

Figure 3. Coacervation phase separation method 


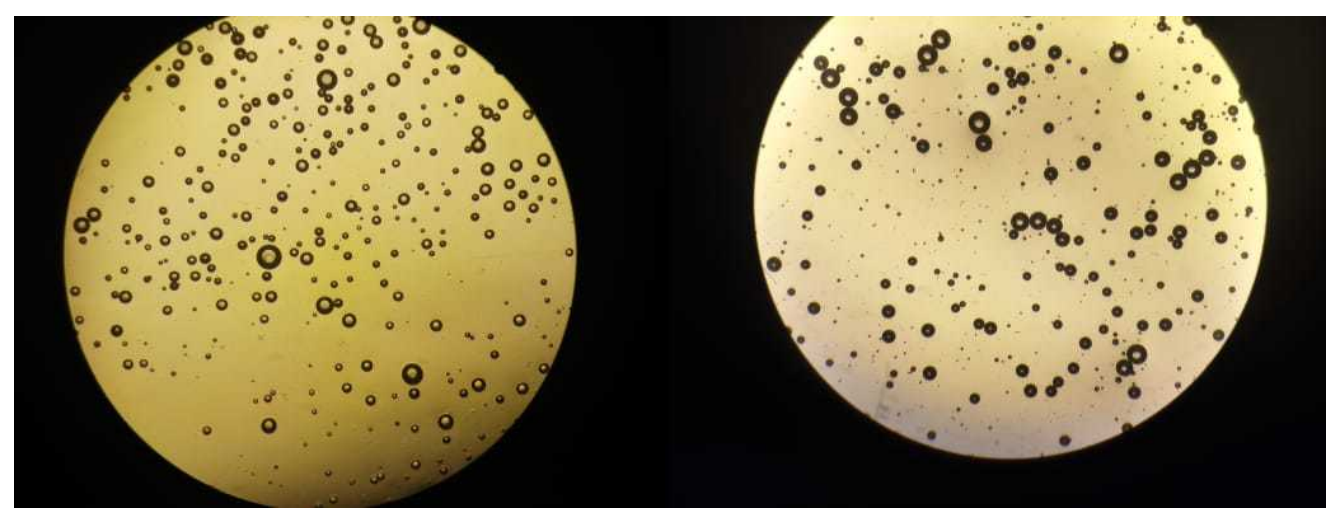

Figure 4. Microscopic image of NLPG2 (Before and after hydration) formed from spans at $100 \mathrm{X}$ magnification $(1-100 \mu \mathrm{m})$

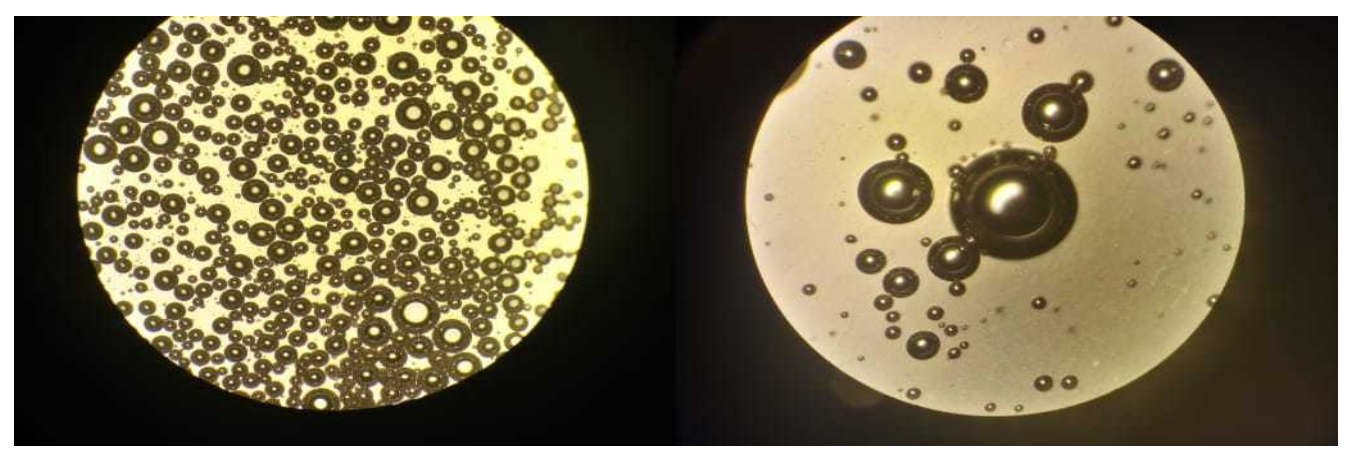

Figure 5. Microscopic image of NLPG3 (Before and after hydration) formed from tweens at $100 \mathrm{X}$ magnification $(1-100 \mu \mathrm{m})$

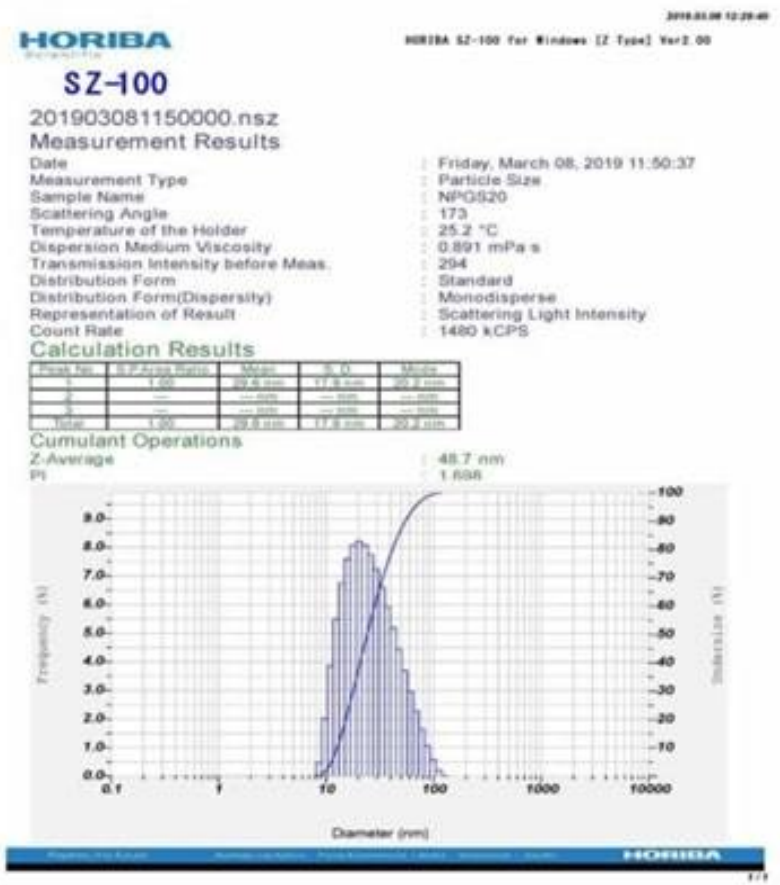

Figure 6. Vesicle size of nanoproniosomal gel of Losartan potassium 


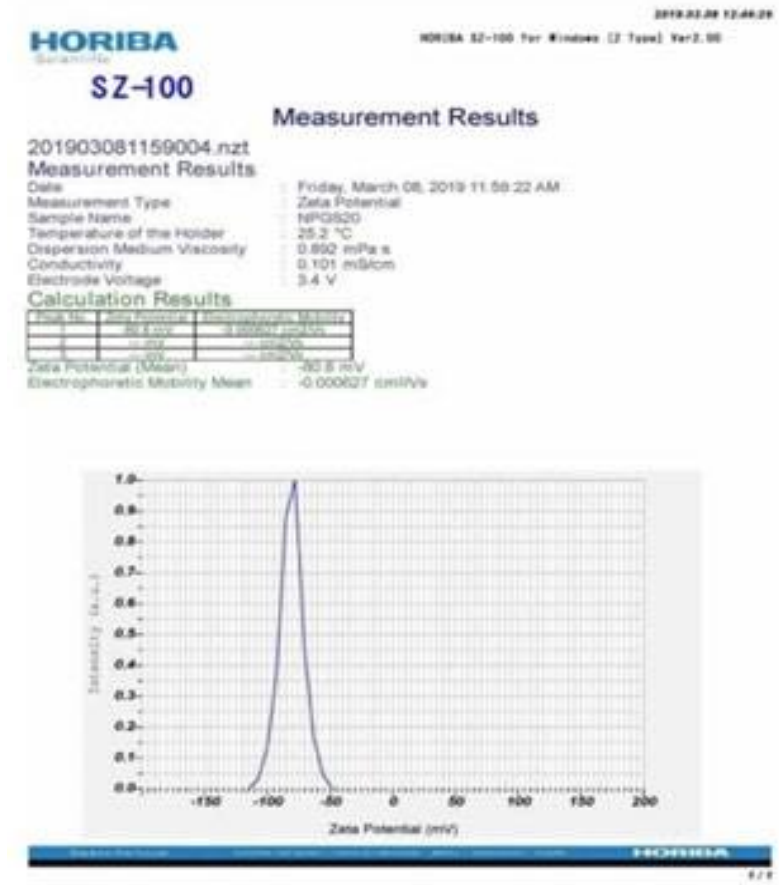

Figure 7. Zeta-Potential of nanoproniosomal gel of Losartan potassium

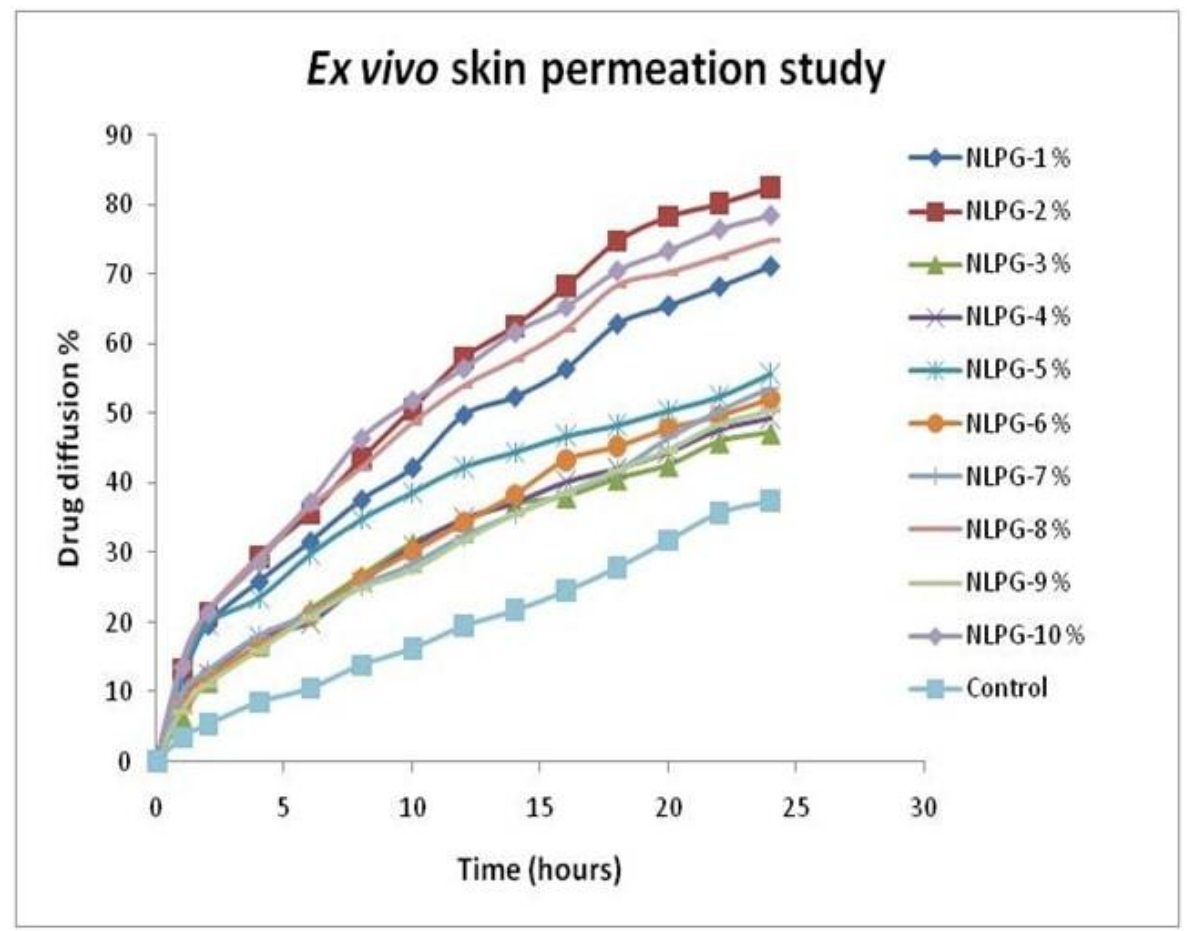

Figure 8. Ex Vivo skin permeation study chart 

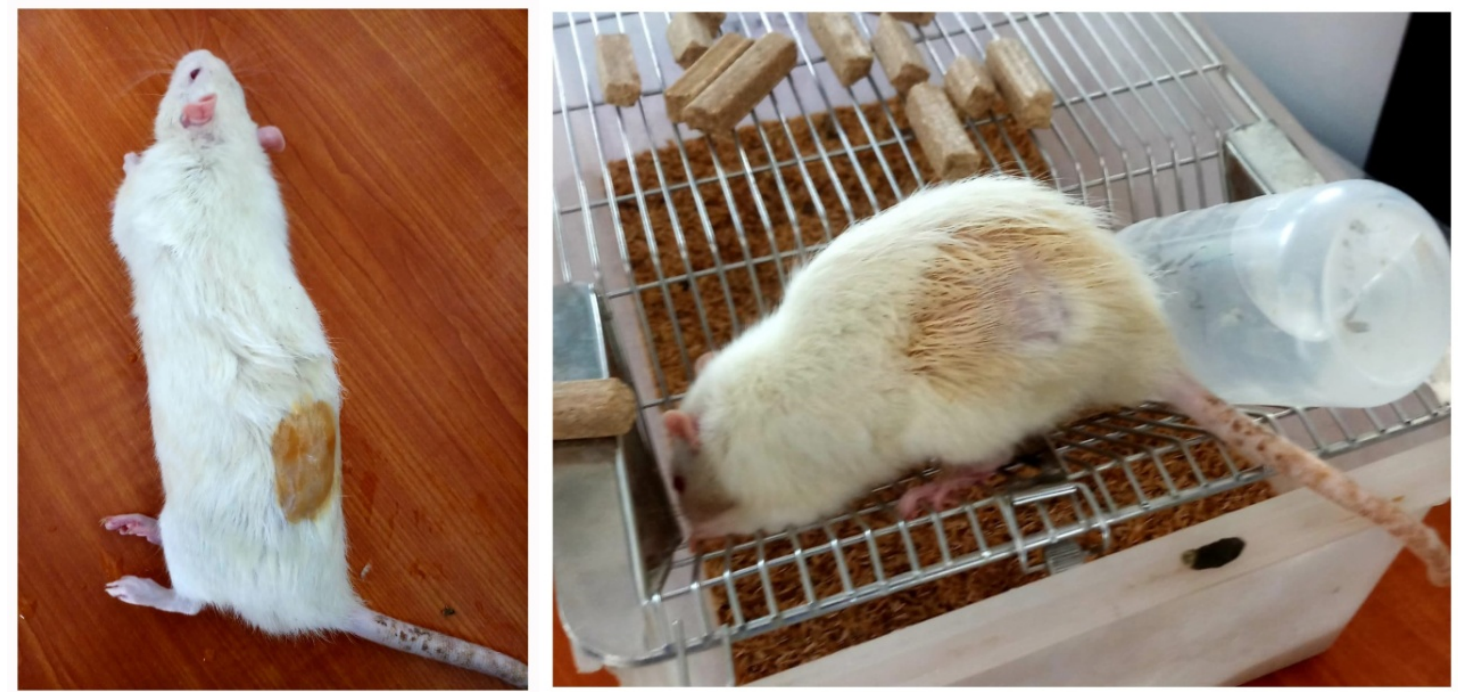

Figure 9. Skin irritation test

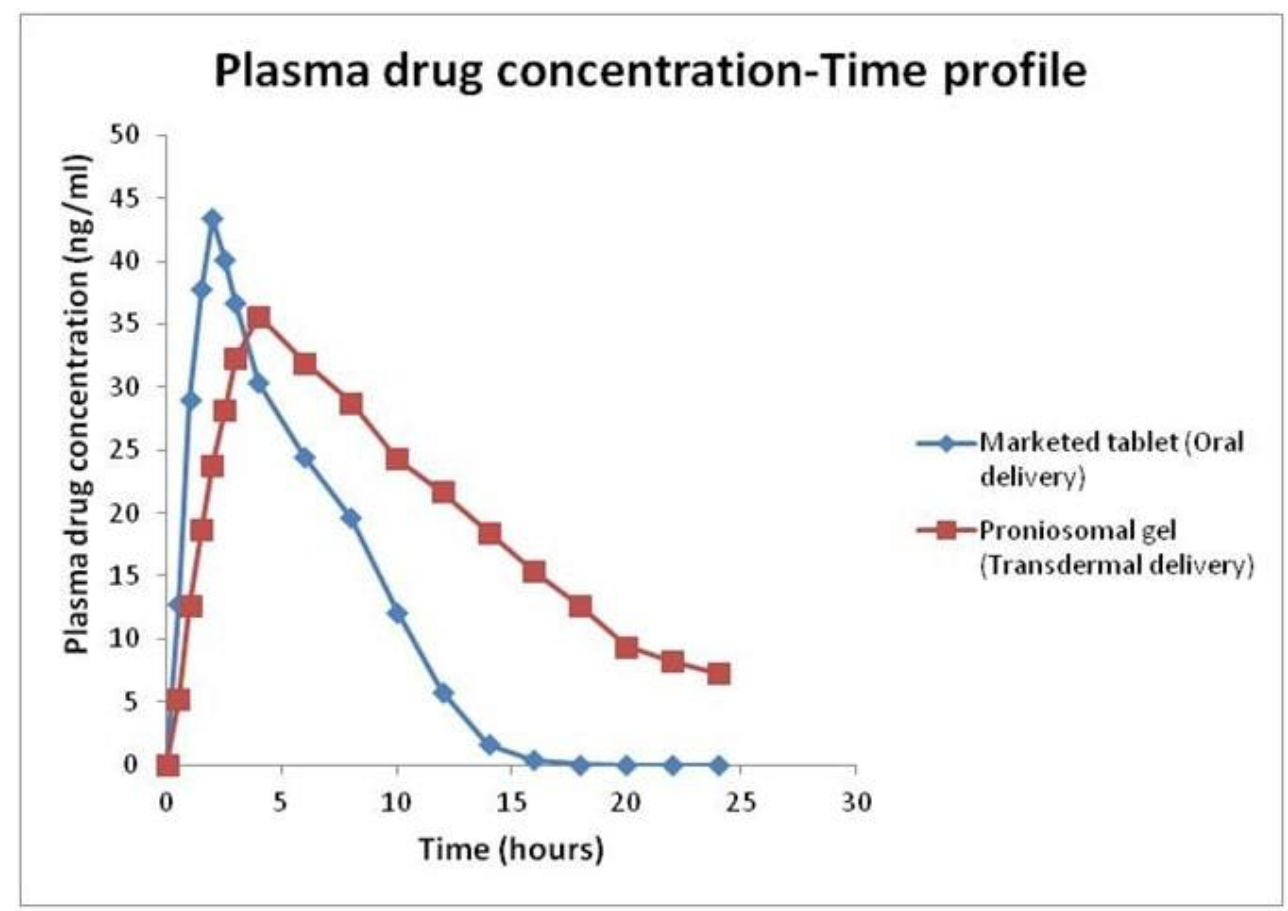

Figure 10. Plasma concentration-time profile of Losartan potassium marketed tablet with Proniosomal gel NLPG2 


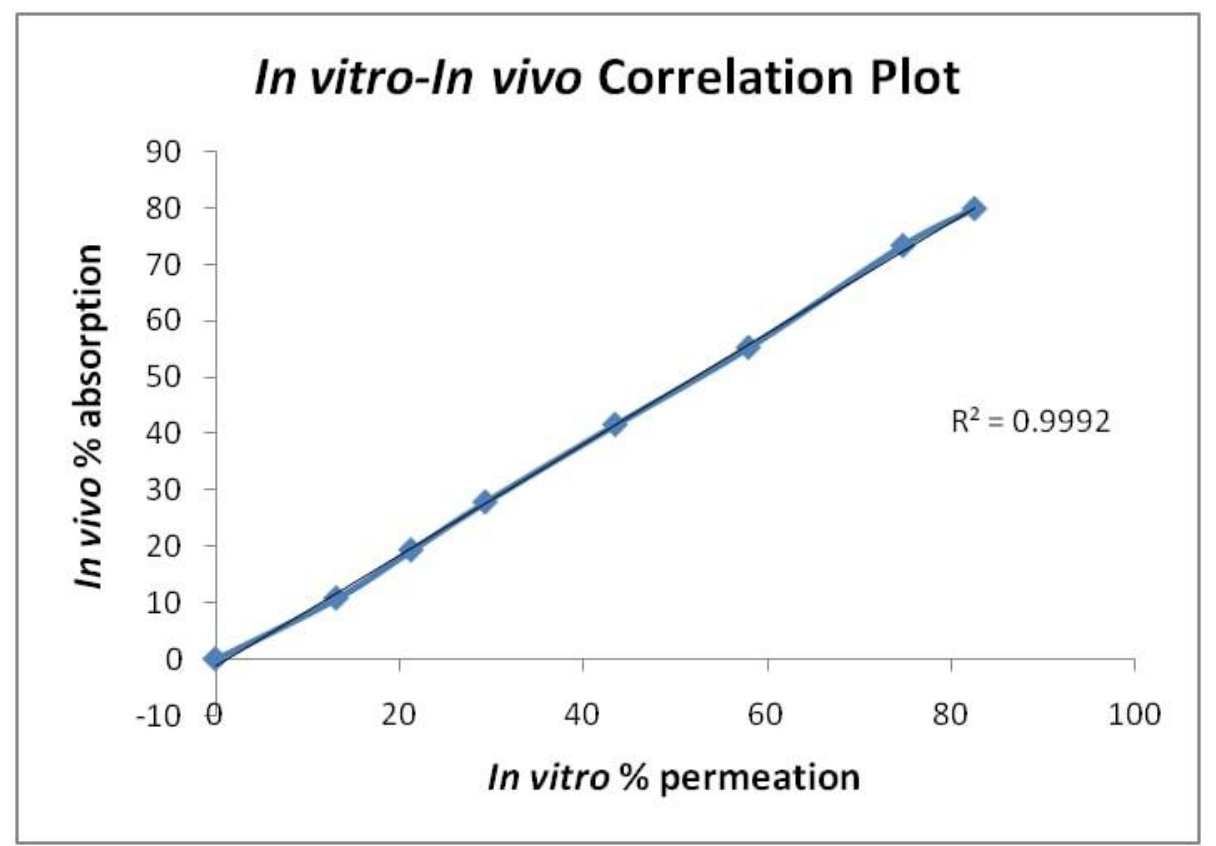

Figure 11. In vitro-In vivo Correlation Plot 